\title{
Genome wide DNA differential methylation regions in colorectal cancer patients in relation to blood related family members, obese and non-obese controls - a preliminary report
}

\author{
S. Pamela K. Shiao, ${ }^{1,2,3}$, Haiyan Xiao', Lixin Dong ${ }^{1}$, Xiaoling Wang ${ }^{2,4}$, Kebin Liu ${ }^{2,5}$, \\ Jinxiong She $\mathbf{S}^{2,3}$ and Huidong $\mathbf{S h} \mathbf{i}^{2,5}$ \\ ${ }^{1}$ College of Nursing, Augusta University, Augusta, GA, USA \\ ${ }^{2}$ Medical College of Georgia, Augusta University, Augusta, GA, USA \\ ${ }^{3}$ Center for Biotechnology and Genomic Medicine, Augusta, GA, USA \\ ${ }^{4}$ Georgia Prevention Institute, Augusta, GA, USA \\ ${ }^{5}$ Georgia Cancer Center, Augusta, GA, USA \\ Correspondence to: S. Pamela K. Shiao, email: pshiao@msn.com; pshiao@augusta.edu \\ Keywords: Genome wide methylation; DNA methylation regions; CRC; blood biomarkers \\ Received: February 20, $2018 \quad$ Accepted: April 25, $2018 \quad$ Published: May 22, 2018 \\ Copyright: Shiao et al. This is an open-access article distributed under the terms of the Creative Commons Attribution License 3.0 \\ (CC BY 3.0), which permits unrestricted use, distribution, and reproduction in any medium, provided the original author and source \\ are credited.
}

\section{ABSTRACT}

Despite evidences linking methylation changes in the cancer tissues, little is known about the methylation modification in the peripheral blood. With the current study, we identified differential methylation regions (DMRs) across human genome by collecting the blood samples of colorectal cancer (CRC) patients compared to that of their blood-related family who shared genetic inheritance and environmental influences, and unrelated obese and non-obese controls by accessing publicly available Gene Expression Omnibus data. We performed genome-wide analyses using the reduced representation bisulfite sequencing (RRBS) method covering about $25 \%$ of CpGs for whole human genome of the four groups ( $n=5$ each). In comparison to the non-obese controls, we observed significant DMRs in CRC for genes involved in tumorigenesis including MLH3, MSH2, MSH6, SEPT9, GNAS; and glucose transporter genes associated with obesity and diabetes including SLC2A1/GLUT1, and SLC2A3/ GLUT3 that were reported on methylation being modified in cancer tissues. In addition, we observed significant DMRs in CRC for genes involved in the methylation pathways including PEMT, ALDH1L1, and DNMT3A. CRC and family members shared significant DMRs for genes of tumorigenesis including MSH2, SEPT9, GNAS, SLC2A1/GLUT1 and SLC2A3/GLUT3); and CAMK1, GLUT1/SLC2A1 and GLUT3/SLC2A3 genes involved in glucose and insulin metabolism that played vital role in development of obesity and diabetes. Our study provided evidences that these differentially methylated genes in the blood could potentially serve as candidate biomarkers for CRC diagnostic and may provide further understanding on CRC progression. Further studies are warranted to validate these methylation changes for diagnostic and prevention of CRC.

\section{INTRODUCTION}

Colorectal cancer $(\mathrm{CRC})$ is the third most common cancer among both men and women, and the third most common cause of cancer-related deaths [1], for past 4 decades in the United States. For 2018, about 97,220 newly diagnosed CRC cases and 50,260 CRCrelated deaths were projected [2]. Genetic mutations and epigenetic modifications in oncogenes and/or tumor suppressor genes cause the development of cancer [3]. 
Given that DNA methylation is one of the most important epigenetic events, the identification of CRC-specific methylation markers may provide new insights for better understanding of $\mathrm{CRC}$ progression and early cancer detection.

Methylation is a reversible attachment of a methyl group to a $\mathrm{CpG}$ dinucleotide, rendering it not being able to be transcribed, affected by both genetic and environmental factors [4-6]. In the past decade, it has become clear that cancer cells have aberrant patterns of DNA methylation at the individual $\mathrm{CpG}$ sites or a group of $\mathrm{CpG}$ sites in close proximity, which are denoted as differentially methylated cytosines (DMCs) and differentially methylated regions (DMRs), respectively [7-9]. For example, it has been reported that some genes are hyper-methylated at the promoter region in $\mathrm{CRC}$ including $A P C, M G M T$ and hMLH1 (see Supplementary Table 1 for the list of genes, full names, and gene functions presented in this paper). Additionally, significant associations were documented between DNA methylation and cancer progression, such as changes of DMR at the promoter region of RASSF $1 A$ gene in association with tumor stages [8]. Additionally, hypermethylation at the promoter regions of SYNE1 and FOXE1 genes was presented in colitis-associated colorectal neoplasia [9]. Most of those studies were focused on tumor tissues to explore the associations between DNA methylation status and CRC as potential biomarkers. Tumor tissue collection would involve invasive approach which is not as readily accessible compared to other less invasive methods such as blood-based detection of CRC. Studies using blood-based methods, however, have relied on testing a limited number of pre-selected genes and on the use of non-quantitative detection methods, such as gel-based methylation-specific polymerase chain reaction (PCR). In the current study we identified different methylation patterns across the whole human genome covering about $25 \%$ of CpGs for whole human genome (see Method section), using the blood samples of CRC patients compared to other controls, with the reduced representation bisulfite sequencing (RRBS) method.

Dietary habits, life-styles and environmental agents contribute to epigenetic changes [10]. For example, a diet rich in polyunsaturated fatty acids could generate mutagenic free radicals and oxidative stress to cause epigenetic alterations [11]. Folate metabolism which also involves Vitamin B12 (both important factors in the onecarbon metabolism pathway), provides the one-carbon units required for intracellular processes, including the synthesis of $\mathrm{S}$-adenosylmethionine (SAM) which is required for DNA methylation and synthesis [12]. Besides genetic inheritance, family members tend to share similar dietary habits, life-styles, and the exposure to the environmental agents. These could result in common epigenetic alterations among the family members and within the family units. However, those probable common signatures among CRC and family members were under studied. In this study, in addition to the CRC cases, we included their blood-related family members living in the same household with the cases who shared not only genetic inheritance but also environmental influences, to examine genome wide methylation profiles of their blood.

Further studies have revealed a risk association for obesity and CRC [13]. Moreover, many studies presented the effects of adiposity on individual genes or methylation processes [14-17]. Adiposity interfered with age-induced epigenetic changes in methylation studies [15] and affected regulatory processes in epigenetic pathways [16]. Obese males are known to have an increased risk of developing CRC compared to non-obese subjects [17]. However, how the methylation processes affect gene ontology for metabolic pathways of CRC is not well documented. Therefore, we included the RRBS based methylation data of obese and non-obese people compared with the data of CRC cases and their blood-related family members.

In summary, with the current study, we analyzed genome wide methylation profiles using blood samples of CRC cases, their blood-related family members, also unrelated obese and non-obese controls. The findings from this study could advance our understanding of how shared genetic inheritance and life experiences within the blood-related family units and adiposity as environmental influences affecting the metabolic processes and epigenetic mechanisms of $\mathrm{CRC}$, which might provide a better insight to the diagnosis, treatment, and prevention of CRC.

\section{RESULTS}

\section{Participants}

The demographic characteristics and $\mathrm{CpG}$ methylation data of the four groups are presented in Table 1. The subjects included 5 CRC patients and their blood-related family members who shared genetic heritage and same household without cancer from a family-based study. Data included RRBS data for these 5 CRC cases and 5 family members, and RRBS data of 5 obese subjects and 5 matched non-obese controls, based on age and gender with the available data, downloaded from the Gene Expression Omnibus (GEO) data that is available to the public (https:// www.ncbi.nlm.nih.gov/geo/query/acc.cgi?acc=GSE85928, see Method section for additional details).

\section{Genome-wide bisulfite sequencing}

To perform a genome-wide analysis of DNA methylation in CRC and family control, in comparison to the obese and non-obese controls, we generated 2050 million Illumina sequencing reads for each sample yielding an average of 6.6 to 7.5 million CpGs which covered $23.2-26.5 \%$ of CpGs for whole human genome (28.3 million CpGs total) $[18,19]$ (Table 1). Of these, 62\% 
Table 1: Sample characteristicsand CpG sequencing data of the four groups

\begin{tabular}{|c|c|c|c|c|}
\hline $\begin{array}{l}\text { n } \\
\text { mean } \pm \text { SD }\end{array}$ & $\begin{array}{l}\text { Control } \\
\mathbf{n}=\mathbf{5}\end{array}$ & $\begin{array}{c}\text { Obesity } \\
n=5\end{array}$ & $\begin{array}{c}\text { Family } \\
n=5\end{array}$ & $\begin{array}{c}\text { Cancer } \\
n=5\end{array}$ \\
\hline \multicolumn{5}{|l|}{ Gender } \\
\hline Female & 3 & 2 & 2 & 5 \\
\hline Male & 2 & 3 & 3 & 0 \\
\hline \multicolumn{5}{|l|}{ BMI } \\
\hline$\leq 30$ & 5 & 0 & 4 & 3 \\
\hline$>30$ & 0 & 5 & 1 & 2 \\
\hline Age & $35 \pm 7$ & $45 \pm 5$ & $31 \pm 13$ & $58 \pm 8$ \\
\hline Raw reads & $\begin{array}{c}34,560,581 \pm \\
17,900,576\end{array}$ & $\begin{array}{c}28,087,864 \pm \\
3,628,196\end{array}$ & $\begin{array}{c}46,728,944 \pm \\
5,939,651\end{array}$ & $\begin{array}{c}34,857,916 \pm \\
5,649,474\end{array}$ \\
\hline QC-passed reads & $\begin{array}{c}24,300,490 \pm \\
12,874,723\end{array}$ & $\begin{array}{c}19,538,524 \pm \\
2,733,127\end{array}$ & $\begin{array}{c}16,917,641 \pm \\
1,803,606\end{array}$ & $\begin{array}{c}12,528,537 \pm \\
1,986,199\end{array}$ \\
\hline Mapping Efficiency & $69.9 \pm 1.44$ & $69.52 \pm 2.31$ & $72.56 \pm 1.95$ & $71.93 \pm 0.88$ \\
\hline \# of CpGs $>0$ read & $6,328,477 \pm 811,790$ & $6,436,231 \pm 697,978$ & $7,458,949 \pm 494,165$ & $6,632,163 \pm 726,277$ \\
\hline \# of CpGs > 5 read & $4,184,837 \pm 479,512$ & $4,291,259 \pm 242,916$ & $4,037,734 \pm 415,253$ & $3,669,350 \pm 342,216$ \\
\hline CpG Methylation $\%$ & $41.7 \pm 0.63$ & $41.51 \pm 1.00$ & $45.69 \pm 2.07$ & $42.6 \pm 2.87$ \\
\hline CpG Coverage & $19.60 \pm 10.06$ & $15.27 \pm 2.84$ & $9.53 \pm 1.14$ & $9.60 \pm 2.36$ \\
\hline \# of CGI & $24,268 \pm 323$ & $24,294 \pm 348$ & $24,483 \pm 143$ & $24,186 \pm 236$ \\
\hline \# of CpGs on CGI & $2,186.183 \pm 281,350$ & $2,195,293 \pm 254,964$ & $2,324,162 \pm 44,814$ & $2,266,921 \pm 77,206$ \\
\hline
\end{tabular}

Note. BMI: body mass index; QC: quality control; CGI: CpG Island.

to $73 \%$ were successfully mapped to either strand of the human genome (hg19). The average sequencing depth per $\mathrm{CpG}$ was between $7 \mathrm{x}$ and $35 \mathrm{x}$. We were able to determine the methylation status of approximately 1.7-2.3 million CpGs on CpG Islands (CGI) (Table 1).

\section{Differentially methylated region (DMR) analysis in 6 regions}

To identify the DMRs between one of the three groups [CRC (Cancer), blood-related family members of CRC patients (Family), and obese] with non-obese control, we then performed a genome-wide unbiased DMR detection using a complete tiling of the human genome in 200 bp windows. Figure 1 is a volcano plot showing the adjusted q-values for all DMRs versus mean methylation difference between each of the three groups and the non-obese control group. Using the criteria requiring an adjusted $\mathrm{q}$ value $<0.05$ and difference of average methylation level $>5 \%, 10 \%$ or $15 \%$, we identified different $\%$ DMRs in each of the three groups when compared with non-obese controls (Table 2 and Supplementary Figure 1). Using a 5\% differential methylation level criterion, we identified a total of 11,866 hyper-methylated DMRs for the Cancer/control pair,
12,700 hyper-methylated DMRs for the Family/control pair, and 2404 hyper-methylated DMRs for the obese/ control pair. Whereas, when a $10 \%$ differential level was used, 4876, 5085, and 1291 hyper-methylated DMRs per pair were identified; and, with a $15 \%$ differential level, 1865, 1784, and 592 hyper-methylated DMRs were noted for the three pairs (Table 2). There were decreased numbers of DMRs as the \% differential levels increased. Additionally, there were 4591 hypo-methylated DMRs for the Cancer/control pair, 2235 hypo-methylated DMRs for the Family/control pair, and 1961 hypo-methylated DMRs for the obese/control pair, when 5\% differential was used as the criterion. The numbers were 2451, 987, and 912 respectively using a $10 \%$ differential criterion; and 1308 , 449 , and 376 of hypo-methylated DMRs respectively for a $15 \%$ criterion.

Overall, there is a trend that more DMRs were presented for the Cancer/control compared to the Family/control, and least DMRs for the obese/control pair, indicating that there were more changes on the methylation for Cancer than the Family and obese groups compared to the non-obese controls. Those results also suggested that genetic and life style that were shared by the blood-related family members might be involved in methylation modifications as more DMRs were found for 
Table 2: Number of hyper- and hypo- differential methylated regions (DMRs) per grouping comparisons at 5\%, $10 \%$, and $15 \%$ differences

\begin{tabular}{lcccccc}
\hline Groups & \multicolumn{2}{c}{ Cancer/Control } & \multicolumn{2}{c}{ Family/Control } & \multicolumn{2}{c}{ Obese/Control } \\
\hline Differential Methylation & Hyper- & Hypo- & Hyper- & Hypo- & Hyper- & Hypo- \\
\hline $5 \%$ & 11,866 & 4591 & 12,700 & 2235 & 2404 & 1961 \\
$10 \%$ & 4876 & 2451 & 5085 & 987 & 1291 & 912 \\
$15 \%$ & 1865 & 1308 & 1784 & 449 & 592 & 376 \\
\hline
\end{tabular}

the Family/control pair compared to the obese/control pair (Table 2 and Supplementary Figure 1). By using a 10\% differential criterion as the methylation difference, we identified the distribution of DMRs in each of the genome regions. Supplementary Table 2 presents that about 5-7\% of the DMRs were presented in the promoter region. $30 \%$ of the DMRs in the Intron region, and $40 \%$ of the DMRs in the intergenic or intragenic regions. The results on these percent distributions were comparable for the three paired group comparisons.

\section{Top 10 methylated DMRs-genes: Cancer versus control pair}

Table 3 lists the top 10 most significant hypermethylated DMRs (distance to transcription start site [TSS] were from $-1,000$ to $+1,000$ base-pair [bp] DNA) for Cancer/control pair, and the annotated genes are PCNXL3, MIR4285, NLGN2, MIR3648, HOXA4, CLDN23, TONSL, GNAS, TUBB8 and MIR1247. Table 4 lists the top 10 most significant hypo-methylated DMRs for Cancer/control pair (Distance to TSS are from -1,000 to $+1,000 \mathrm{bp}$ ). The annotated genes are $S L C 2 A 3$ (GLUT3), LOC338817, MLH3, LRRC27, FANCG, RPSA, SLC2A1 (GLUT1), ZFP36, HMHA1, and ARID5B. Many of those genes had been shown to be differently expressed in CRC tumor tissues, that were also presented in our study using the blood samples. Thus, those methylation changes could be potential biomarkers in the blood for CRC diagnostic or provide further understanding on CRC development. It is worthy to notice that half of the hyper-methylated DMRs were in the DNA coding sequence (CDS) regions as compared to the other half in other combination of promoter, five prime untranslated (Utr5) and intron regions; whereas, half of the hypo-methylated DMRs were in the promoter regions as compared to the other half being the combination of intron, CDS, and Utr5 regions.

\section{Top 10 methylated DMRs-genes: Family versus control pair}

Top 10 hyper-methylated DMRs for Family/ control pair are listed in Supplementary Table 3, the annotated genes are PCNXL3, RFPL2, LOC729176, TONSL, NLGN2, GNAS, TPRX1, EGFLAM, PRKAR1B, and MIR3648 (genes underlined are overlapping with genes found for the Cancer/control pair in Table 3). Supplementary Table 4 lists top 10 hypo-methylated DMRs for Family/control, and the related genes are SLC2A3, LOC338817, SLC2A1 (GLUT1), METTL16, SEPT9, MEG3, HMHA1, HOXB6, CPOX, and SLC2A3 (GLUT3) (genes underlined are overlapping with genes found for the Cancer/control pair in Table 4). Interestingly, among those top 10 hyper- and hypo- methylated genes, several of them are overlapping with those in Cancer/ control pair, including PCNXL3, TONSL, NLGN2, GNAS, MIR3648, SLC2A3 (GLUT3) and SLC2A1 (GLUT1). This finding supports the hypothesis that blood-related family members shared similar epigenetic modifications with $\mathrm{CRC}$ patients, as they shared genetic heritage and might have also shared similar dietary habits, life style, and environmental agents in the same household in addition to their genetic makeup. It is worthy to notice that hypermethylated DMRs were about evenly distributed in the CDS, promoter, intron and Utr5 regions; whereas, half of the hypo-methylated DMRs were in the promoter, and other half in intron regions (40\%), and finally in Utr5 regions.

\section{Top 10 methylated DMRs-genes: Obesity versus control pair}

Supplementary Table 5 presents top 10 hypermethylated DMRs for obese/control pair, and the genes are RGPD5/RGPD8, CTDSPL2, GCNT1, LMO2, PGPEP1L, LDHA, CYB5R2, SPACA1, PARVG, and MSH6. Top 10 hypo-methylated DMRs for obese/control are listed in Supplementary Table 6. The annotated genes are LHX6, INPP5F, HIGD1A, SLC2A3 (GLUT3), BLCAP, NNAT, MATR3, SNHG4, CCDC144B, and DTX1 (gene underlined is also found for the Cancer versus control pair in Table 4). And, $S L C 2 A 3$ was also on the top 10 hypomethylated gene list in Cancer/control pair comparison, which suggested some association of obesity and CRC. It is worthy to notice that hyper-methylated DMRs are about evenly distributed in the CDS, promoter, intron and Utr5 regions; whereas, more regions of the hypo-methylated DMRs are in the promoter $(40 \%)$, than intron $(30 \%)$ and other three regions of CDS, Utr5 and three prime untranslated (Utr3) regions (10\% each). 
Table 3: Top 10 hyper-methylated DNA methylated regions based on $10 \%$ difference between Cancer and Control $(-1000 \leq$ distance to transcription start site $[\mathrm{TSS}] \leq+1000$ base-pair DNA)

\begin{tabular}{|c|c|c|c|c|c|c|c|c|}
\hline \multirow[t]{2}{*}{ Gene } & \multirow[t]{2}{*}{ Regions } & \multicolumn{2}{|c|}{ DMR location } & \multirow{2}{*}{$\begin{array}{l}\text { Distance } \\
\text { To TSS }\end{array}$} & \multicolumn{3}{|c|}{ Methylation Difference } & \multirow[t]{2}{*}{ Gene Name or Role } \\
\hline & & Start & End & & $\%$ & $p$ & $q$ & \\
\hline PCNXL3 & CDS & $65,402,926$ & $65,403,007$ & -774 & 39.49 & $3.20 \mathrm{E}-13$ & $1.63 \mathrm{E}-11$ & $\begin{array}{l}\text { Homeostasis/ } \\
\text { metabolism } \\
\text { phenotype }\end{array}$ \\
\hline MIR4285 & Utr5 & $101,936,380$ & $101,936,461$ & 13 & 38.53 & $4.00 \mathrm{E}-07$ & $2.85 \mathrm{E}-06$ & MicroRNA 4285 \\
\hline$N L G N 2$ & CDS & $7,311,698$ & $7,311,857$ & 198 & 34.28 & $9.29 \mathrm{E}-05$ & $2.72 \mathrm{E}-04$ & $\begin{array}{l}\text { Mediates cell-cell } \\
\text { interactions and } \\
\text { modulates insulin } \\
\text { secretion }\end{array}$ \\
\hline MIR3648 & Utr5 & $9,825,819$ & $9,826,028$ & 0 & 33.93 & $5.21 \mathrm{E}-21$ & $3.53 \mathrm{E}-18$ & MicroRNA 3648 \\
\hline HOXA4 & CDS & $27,169,637$ & $27,170,022$ & 378 & 31.68 & $2.04 \mathrm{E}-03$ & $3.40 \mathrm{E}-03$ & $\begin{array}{l}\text { Sequence-specific } \\
\text { DNA binding } \\
\text { transcription factor } \\
\text { activity }\end{array}$ \\
\hline$C L D N 23$ & CDS & $8,560,299$ & $8,560,499$ & 635 & 31.19 & $1.56 \mathrm{E}-04$ & 4.17E-04 & $\begin{array}{l}\text { Structural molecule } \\
\text { activityidentical } \\
\text { protein binding }\end{array}$ \\
\hline TONSL & $\mathrm{CDS}$ & $145,661,276$ & $145,661,402$ & -275 & 31.03 & $3.44 \mathrm{E}-10$ & 7.12E-09 & $\begin{array}{l}\text { Transcription } \\
\text { corepressor activity }\end{array}$ \\
\hline$G N A S$ & Promoter & $57,464,802$ & $57,465,121$ & 624 & 28.79 & $3.48 \mathrm{E}-04$ & 8.05E-04 & $\begin{array}{l}\text { Insulin-like growth } \\
\text { factor receptor } \\
\text { binding }\end{array}$ \\
\hline$T U B B 8$ & Intron & 95,010 & 95,073 & 106 & 27.79 & $4.90 \mathrm{E}-04$ & $1.07 \mathrm{E}-03$ & $\begin{array}{l}\text { Structural } \\
\text { constituent of } \\
\text { cytoskeleton }\end{array}$ \\
\hline MIR1247 & Promoter & $102,028,543$ & $102,0128,738$ & 857 & 27.63 & $5.44 \mathrm{E}-05$ & $1.75 \mathrm{E}-04$ & MicroRNA 1247 \\
\hline
\end{tabular}

Note: CDS: coding DNA sequence; Utr5: five prime untranslated.

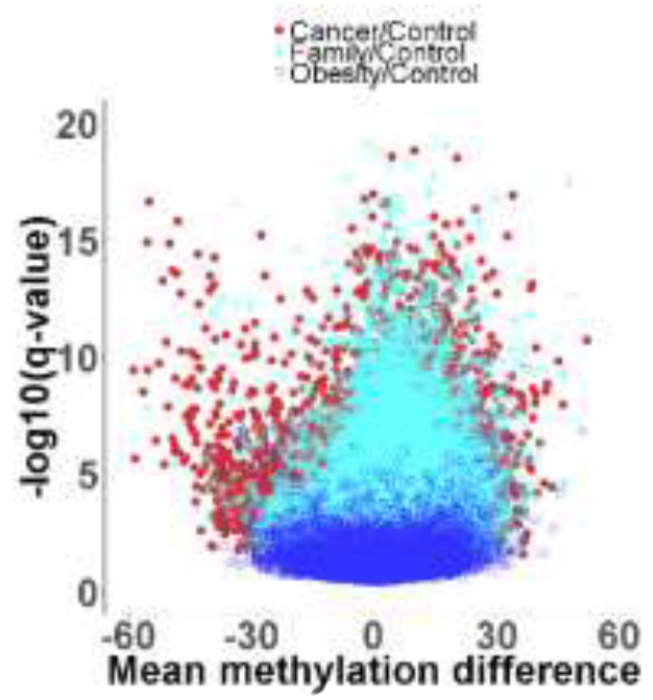

Figure 1: Volcano plot showing adjusted q values versus mean methylation difference between groups of Cancer (red color), Family (teal color), and Obese (blue color) with non-obese Control. 
Table 4: Top 10 hypo-methylated DNA methylated regions based on $10 \%$ difference between Cancer and Control (-1000 $\leq$ distance to transcription start site $[\mathrm{TSS}] \leq+1000$ base-pair DNA)

\begin{tabular}{|c|c|c|c|c|c|c|c|c|}
\hline \multirow[t]{2}{*}{ Gene } & \multirow[t]{2}{*}{ Regions } & \multicolumn{2}{|c|}{ DMR location } & \multirow{2}{*}{$\begin{array}{c}\text { Distance } \\
\text { To TSS }\end{array}$} & \multicolumn{3}{|c|}{ Methylation Difference } & \multirow{2}{*}{$\begin{array}{l}\text { Gene Name or } \\
\text { role }\end{array}$} \\
\hline & & Start & End & & $\%$ & $p$ & $q$ & \\
\hline$S L C 2 A 3$ & Intron & $8,087,820$ & $8,087,905$ & 988 & -61.18 & $1.06 \mathrm{E}-13$ & $6.23 \mathrm{E}-12$ & $\begin{array}{l}\text { Glucose } \\
\text { transmembrane } \\
\text { transporter activity }\end{array}$ \\
\hline LOC338817 & Promoter & $11,700,194$ & $11,700,609$ & -355 & -55.46 & $1.36 \mathrm{E}-18$ & $3.92 \mathrm{E}-16$ & N/A \\
\hline MLH3 & Promoter & $75,518,893$ & $75,518,943$ & -659 & -51.32 & $2.22 \mathrm{E}-07$ & $1.73 \mathrm{E}-06$ & $\begin{array}{l}\text { DNA Mismatch } \\
\text { Repair (MMR) }\end{array}$ \\
\hline$L R R C 27$ & Promoter & $134,144,308$ & $134,144,429$ & 951 & -49.30 & $1.06 \mathrm{E}-08$ & $1.32 \mathrm{E}-07$ & $\begin{array}{l}\text { Leucine Rich } \\
\text { Repeat Containing } \\
27\end{array}$ \\
\hline FANCG & Promoter & $35,080,807$ & $35,080,913$ & -795 & -48.79 & $2.24 \mathrm{E}-08$ & $2.51 \mathrm{E}-07$ & $\begin{array}{l}\text { DNA Double- } \\
\text { Strand Break } \\
\text { Repair }\end{array}$ \\
\hline$R P S A$ & Intron & $39,450,361$ & $39,450,501$ & 481 & -46.51 & $1.53 \mathrm{E}-07$ & $1.27 \mathrm{E}-06$ & $\begin{array}{l}\text { RNA binding, } \\
\text { structural } \\
\text { constituent of } \\
\text { ribosome }\end{array}$ \\
\hline$S L C 2 A 1$ & Promoter & $43,425,368$ & $43,425,715$ & -522 & -44.71 & $8.39 \mathrm{E}-10$ & $1.51 \mathrm{E}-08$ & $\begin{array}{l}\text { Glucose } \\
\text { transmembrane } \\
\text { transporter activity }\end{array}$ \\
\hline ZFP36 & CDS & $39,899,297$ & $39,899,354$ & 965 & -43.30 & $2.97 \mathrm{E}-06$ & $1.56 \mathrm{E}-05$ & $\begin{array}{l}\text { DNA binding, RNA } \\
\text { binding, Protein } \\
\text { binding }\end{array}$ \\
\hline HМHАI & Intron & $1,077,542$ & $1,077,680$ & 911 & -42.82 & $3.24 \mathrm{E}-12$ & $1.23 \mathrm{E}-10$ & $\begin{array}{l}\text { Minor } \\
\text { histocompatibility } \\
\text { protein HA-1 }\end{array}$ \\
\hline ARID 5B & Utr5 & $63,808,928$ & $63,809,171$ & 0 & -42.54 & $6.81 \mathrm{E}-07$ & 4.50E-06 & $\begin{array}{l}\text { FTO Obesity } \\
\text { Variant Mechanism }\end{array}$ \\
\hline
\end{tabular}

Note: CDS: coding DNA sequence.

\section{Targeted genes}

For additional genes of significance between Cancer versus control groups, Table 5 presents hypermethylated DMRs, with Figure 2 presenting the three most representative genes, $\boldsymbol{G N A S ,} \boldsymbol{M S H}$, and $\boldsymbol{C A M K}$ that were significantly different for Case/control and Family/ control pairs, and Supplementary Figure 2 presenting additional genes of significance for Cancer/control pair. And, Table 6 presents significant hypo-methylated DMRs and associated genes that showed difference between Cancer versus control groups, with Figure 3 presenting the three most representative genes, SEPT9, SLC2A1/ GLUT1 and SLC2A3/GLUT3, that were significantly different for both Cancer/control and Family/control pairs, and Supplementary Figure 3 presenting additional genes of significance for Cancer/control pair.

Figure 2 displays the significant hyper-methylated DMRs with the specific genes. The data reflects an increase in the methylation levels of some DMRs incrementally from control, obese, and Family, to Cancer groups. Pair-wise tests presented significant $(p<0.05)$ hyper-methylated genes between Cancer/control and Family/control pairs, on $\boldsymbol{G N} \boldsymbol{A S}$ at the promoter region, $\mathbf{M S H 2}$ at the Intron region, and CAMK2 at the CDS region (Figure 2). Additional genes with significant trends for group differences for hyper-methylaton included $H K 3, F C N 1$, and NOS3 at the CDS region; and, DNMT3A and MSH6 at the intron region (Supplementary Figure 2). Those results suggested common methylation alterations exist in CRC and their family members by sharing genetic heritage, household environment, and epigenetic changes.

Figure 3 presents the significant hypo-methylated DMRs with the specific genes. The data reflects a decrease in the methylation levels of some DMRs from control, obese, and Family to Cancer groups. Pair-wise tests presented significant $(p<0.05)$ hypo-methylated 
Table 5: Significant hyper-methylated genes based on $\mathbf{1 0 \%}$ methylation difference between Cancer and Control $(-1000 \leq$ distance to transcription start site $[\mathrm{TSS}] \leq+1000$ base-pair DNA)

\begin{tabular}{|c|c|c|c|c|c|c|c|c|}
\hline \multirow[t]{2}{*}{ Gene } & \multirow[t]{2}{*}{ Regions } & \multicolumn{2}{|c|}{ DMR location } & \multirow{2}{*}{$\begin{array}{l}\text { Distance } \\
\text { To TSS }\end{array}$} & \multicolumn{3}{|c|}{ Methylation Difference } & \multirow[t]{2}{*}{ Gene Role } \\
\hline & & Start & End & & $\%$ & $p$ & $q$ & \\
\hline \multirow[t]{2}{*}{ GNAS } & Promoter & $57,464,802$ & $57,465,121$ & 624 & 28.79 & $3.48 \mathrm{E}-04$ & $8.05 \mathrm{E}-04$ & GNAS mutation \\
\hline & Promoter & $57,425,903$ & $57,426,055$ & 0 & 26.79 & $1.59 \mathrm{E}-06$ & $9.22 \mathrm{E}-06$ & $\begin{array}{l}\text { associated } \\
\text { with colorectal } \\
\text { tumorigenesis [30] }\end{array}$ \\
\hline DNMT3A & Intron & $25,551,093$ & $25,551,226$ & 365 & 23.78 & 8.39E-07 & $5.36 \mathrm{E}-06$ & $\begin{array}{l}\text { Methylation } \\
\text { pathway }\end{array}$ \\
\hline MSH6 & Intron & $48,011,362$ & $48,011,896$ & 270 & 20.76 & $2.71 \mathrm{E}-03$ & $4.28 \mathrm{E}-03$ & $\begin{array}{l}\text { Lynch Syndrome, } \\
\text { MMR }\end{array}$ \\
\hline$C A M K 1$ & CDS & $9,799,262$ & $9,799,361$ & 7,636 & 15.32 & $1.06 \mathrm{E}-04$ & $3.03 \mathrm{E}-04$ & $\begin{array}{l}\text { Calcium/ } \\
\text { calmodulin- } \\
\text { dependent protein } \\
\text { kinase type } 1\end{array}$ \\
\hline MSH2 & Intron & $47,660,208$ & $47,660,258$ & 30,004 & 14.75 & $1.08 \mathrm{E}-04$ & $3.07 \mathrm{E}-04$ & $\begin{array}{l}\text { Lynch Syndrome, } \\
\text { MMR }\end{array}$ \\
\hline GNAS & Intron & $57,416,524$ & $57,416,680$ & 0 & 14.50 & $9.23 \mathrm{E}-04$ & $1.79 \mathrm{E}-03$ & $\begin{array}{l}\text { Associated } \\
\text { with colorectal } \\
\text { tumorigenesis }\end{array}$ \\
\hline$H K 3$ & CDS & $176,308,803$ & $176,309,092$ & 17,242 & 14.45 & $3.26 \mathrm{E}-05$ & $1.16 \mathrm{E}-04$ & $\begin{array}{l}\text { Glucose } \\
\text { metabolism } \\
\text { pathways }\end{array}$ \\
\hline GNAS & Promoter & $57,426,743$ & $57,427,047$ & -786 & 13.72 & $6.80 \mathrm{E}-03$ & $9.05 \mathrm{E}-03$ & $\begin{array}{l}\text { GNAS mutation } \\
\text { associated with } \\
\text { Cancer }\end{array}$ \\
\hline FCN1 & CDS & $137,804,570$ & $137,805,004$ & 4,803 & 11.72 & $7.28 \mathrm{E}-05$ & $2.23 \mathrm{E}-04$ & $\begin{array}{l}\text { Associated with } \\
\text { Diabetes }\end{array}$ \\
\hline$H K 3$ & CDS & $176,314,364$ & $176,314,772$ & 11,562 & 11.32 & $1.07 \mathrm{E}-02$ & $1.31 \mathrm{E}-02$ & $\begin{array}{l}\text { Glucose } \\
\text { metabolism } \\
\text { pathways }\end{array}$ \\
\hline NOS3 & CDS & $150,710,282$ & $150,710,719$ & 10,868 & 10.69 & $2.45 \mathrm{E}-02$ & $2.66 \mathrm{E}-02$ & $\begin{array}{l}\text { Methylation, } \\
\text { oxidative stress }\end{array}$ \\
\hline
\end{tabular}

Note: CDS: coding DNA sequence.

genes between Cancer/control and Family/control pairs on SEPT9 at the intron region, SLC2A1/GLUT1 at the promoter region, and $\boldsymbol{S L C 2 A 3 / G L U T 3}$ at the intron region (Figure 3). Additional genes with significance or significant trends for Cancer/control group differences included FCN1 and PEMT at the intron region (Supplementary Figure 3). Those results suggested common methylation alterations exist in CRC and their family members by sharing genetic heritage, household environment, and epigenetic changes. On the other hand, it also suggested that obesity might be associated with CRC as the methylation levels of some of these genes for the obese group are in the mid-range between the CRC and control groups (Figures 2 and 3, Supplementary Figures 2 and Supplementary Figure 3).
Five of these six significant genes shared by Cancer/ control and Family/control pairs presented in Figures 2 and 3 , in addition to other genes play significant roles in cancer development or tumorigenesis (e.g. MLH3, MSH2, MSH6, SEPT9, GNAS, SLC2A1/GLUT1 and SLC2A3/ $\boldsymbol{G L U T}$ [20-22]. MSH2 and MSH6 are DNA mis-match repair (MMR) genes for family based hereditary CRC], Lynch Syndrome. Variations in those genes markedly increases the risk of developing Lynch Syndrome [20-22] (also named hereditary nonpolyposis colorectal cancer, HNPCC), which is an inherited disorder that increases the risk of many types of cancer including CRC. MLH3is also a MMR, which also plays an important role in HNPCC [23]. The role of SLC2A1/GLUT1 and SLC2A3/GLUT3 
Table 6: Significant Genes based on $10 \%$ differences of methylation level between Cancer and Control (hypomethylated genes)

\begin{tabular}{|c|c|c|c|c|c|c|c|c|}
\hline \multirow[t]{2}{*}{ Gene } & \multirow[t]{2}{*}{ Regions } & \multicolumn{2}{|c|}{ DMR location } & \multirow{2}{*}{$\begin{array}{c}\text { Distance } \\
\text { To TSS }\end{array}$} & \multicolumn{3}{|c|}{ Methylation Difference } & \multirow[t]{2}{*}{ Gene Role } \\
\hline & & Start & End & & $\%$ & $P$ & $q$ & \\
\hline$S L C 2 A 3$ & Intron & $8,087,820$ & $8,087,905$ & 988 & -61.18 & $1.06 \mathrm{E}-13$ & $6.23 \mathrm{E}-12$ & $\begin{array}{l}\text { Glucose } \\
\text { transporter } \\
3 \text { (GLUT3) }\end{array}$ \\
\hline$M L H 3$ & Promoter & $75,518,893$ & $75,518,943$ & -659 & -51.32 & $2.22 \mathrm{E}-07$ & $1.73 \mathrm{E}-06$ & $\begin{array}{l}\text { DNA } \\
\text { mismatch } \\
\text { repair genes }\end{array}$ \\
\hline$S L C 2 A 1$ & Promoter & $43,425,368$ & $43,425,715$ & -522 & -44.71 & $8.39 \mathrm{E}-10$ & $1.51 \mathrm{E}-08$ & $\begin{array}{l}\text { Glucose } \\
\text { transporter } \\
1 \text { (GLUT1) }\end{array}$ \\
\hline FCN1 & Intron & $137,802,212$ & $137,802,301$ & 7,506 & -28.36 & $6.39 \mathrm{E}-04$ & $1.33 \mathrm{E}-03$ & $\begin{array}{l}\text { Associated } \\
\text { with } \\
\text { Diabetes }\end{array}$ \\
\hline SEPTP & Intron & $75,449,408$ & $75,450,396$ & 0 & -27.68 & $2.50 \mathrm{E}-09$ & $3.82 \mathrm{E}-08$ & $\begin{array}{l}\text { Tumor } \\
\text { suppressor } \\
\text { gene }\end{array}$ \\
\hline PEMT & Intron & $17,410,253$ & $17,410,397$ & $-10,545$ & -23.01 & $9.47 \mathrm{E}-05$ & $2.77 \mathrm{E}-04$ & $\begin{array}{l}\text { Methylation } \\
\text { pathway }\end{array}$ \\
\hline$A L D H 1 L 1$ & Intron & $125,832,461$ & $125,832,876$ & 9,980 & -11.08 & $9.75 \mathrm{E}-04$ & $1.86 \mathrm{E}-03$ & $\begin{array}{l}\text { Methylation } \\
\text { pathway }\end{array}$ \\
\hline
\end{tabular}

has been widely studied in cancers [24-27]. Researchers summarized that GLUT1 was associated with poor prognosis for disease-free survival in rectal cancer and an indicator of aggressive clinical features in CRC through a meta-analysis [28]. SEPT9 has been reported as being a promising biomarker for early detection and screening of CRC $[29,30]$, which is also presented in our results using the blood samples. HK3, FCN1, CAMK1, GLUT1/SLC2A1 and $G L U T 3 / S L C 2 A 3$ are involved in glucose and insulin metabolism that played vital role in development of obesity and diabetes. FCNlgene is associated with an earlier onset of type 1 diabetes mellitus in children and adolescents
[31]. PEMT, ALDH1L1, DNMT3A are critical genes in the methylation pathways. DNMT3A is also reported as one of the critical tumor suppressor genes, has crucial biological role in self-renewing cells, enabling their differentiation. Its dysregulation could result in a predisposition to cancer and other pathological consequences [32].

\section{Gene ontology analysis}

For gene ontology analysis, we used 15\% differences of average methylation level as the criterion on the DMRs. For Cancer/control pair, from 3173
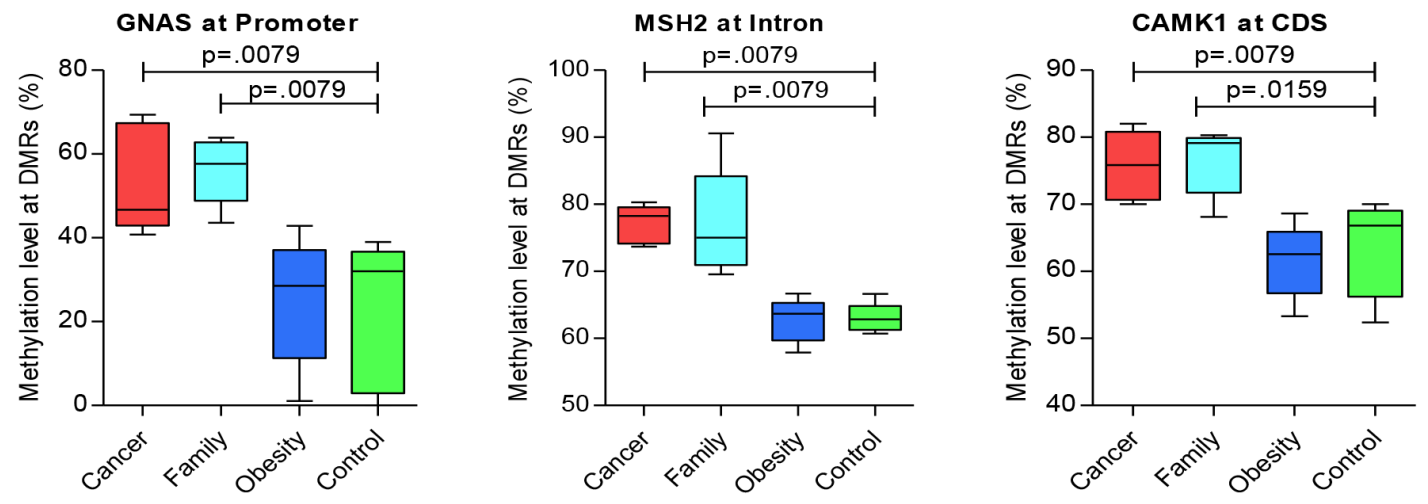

Figure 2: Significant genes of hyper-methylation compared between groups (CDS: coding DNA sequence region). 
DMRs (adjusted $q<0.05$ ), we identified 1778 known genes. Those genes were uploaded onto the Database for Annotation, Visualization and Integrated Discovery (DAVID) (https://david.ncifcrf.gov), National Institutes of Health [33-35], for Gene Ontology analysis to study whether some common functional trends in pathways, biological processes, cellular component and molecular functions were associated with those genes. Table 7 lists the Kyoto Encyclopedia of Genes and Genomes (KEGG) PATHWAY and Gene Ontology (GO) categories from DAVID with both raw $p$ value and Benjamini value to correct for false discovery rate (FDR), of less than 0.05 .

For the KEGG Pathway analysis, five pathways survived FDR for multiple testing corrections, including Axon Guidance (hsa04360), Pathways in Cancer (hsa05200), Rap1 Signaling Pathway (hsa04015), Focal Adhesion (hsa04510), and Glutamatergic Synapse (hsa04724). It has been reported that Axon Guidance gene could turn off tumor suppressor gene in CRC which explains why this pathway survived in Cancer/control pair comparative analysis [36]. Pathways in Cancer, Rap1 Signaling Pathway, and Focal Adhesion were all reported to being involved in cancer development [37-39]. Researchers showed that Rap1 Signaling Pathway played an important role in regulating tumor cell invasion and metastasis [40]. Dysregulated Glutamatergic Signaling Pathways were found as being a player in brain tumor and melanoma [41]. Therefore, all five observed pathways are consistent with the cancer status when compared to the healthy non-obese control data.

We also observed 7 biological processes that exhibited differences between Cancer and control. Those process includes Hemophilic Cell Adhesion via Plasma Membrane Adhesion Molecules (GO: 0007156), Signal Transduction (GO: 0007165), Positive Regulation of GTPase Activity (GO: 0043547), Neuromuscular Process Controlling Balance (GO: 0050885), Cell Adhesion (GO: 0007155), Nervous System Development (GO: 0007399), and Cell Migration (GO: 0016477). There was one cellular function and one molecular function survived
FDR for multiple testing, named Plasma Membrane (GO: 0005886) and Calcium Ion Binding (GO: 0005509).

For Family/Control pair, from 2233 DMRs (adjusted $q<0.05$ ), we identified 1210 known genes. GO analysis was performed using those genes and DAVID database. However, only one molecular function showed significant difference between Family/control pair, which is Calmodulin Binding (GO: 0005516). Although Family/ control pair shared some significant DMRs overlapping with the DMRs for Cancer/control pair, no pathways and only one molecular function survived the FDR on gene ontology tests. This may explain why Cancer group developed CRC while Family group did not.

For obese/control pair, from the 968 DMRs (adjusted $q<0.05$ ), we identified 617 known genes. GO analysis resulted only one significant biological process, one significant cellular component and one significant molecular function, named Homophilic Cell Adhesion via Plasma Membrane Adhesion Molecules (GO: 0007156), Plasma Membrane (GO: 0005886) and Calcium Ion Binding (GO: 0005509) respectively. All three categories showed up on Cancer/control pair comparative analysis, indicating that there might be some associations in the development of diseases for CRC and adiposity.

\section{DISCUSSION}

In this study, we determined the methylation status of approximately $25 \%$ of CpGs for the entire human genome, using RRBS of blood samples, for the CRC patients and their family members, with the obese and non-obese healthy controls from GEO database. These CpGs were highly enriched in CGI regions. Over 23,000 CGIs were examined in each sample from all four groups. To our knowledge, this is the first sequencing-based methylation study of the blood samples for CRC and their blood-related family members. We also included data from obese and non-obese healthy control participants, accessed from GEO public data to study the common and different epigenetic alterations in $\mathrm{CRC}$ and family compared to these controls. After
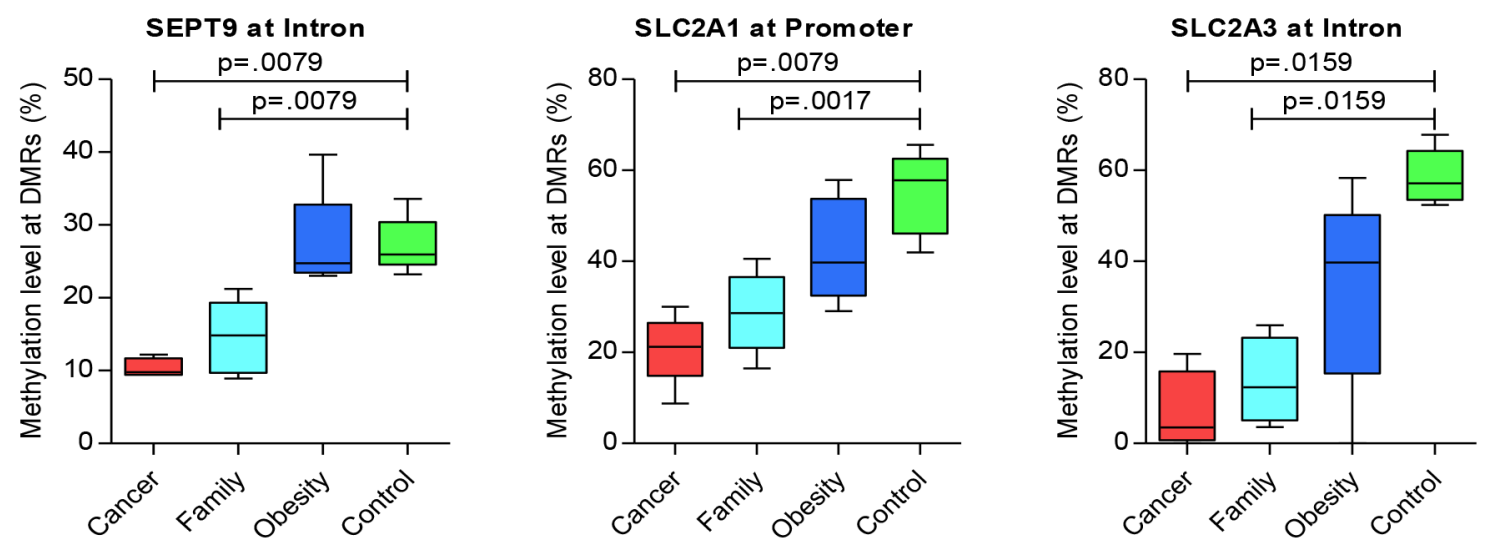

Figure 3: Significant genes of hypo-methylation compared between groups. 
Table 7: Gene Ontology (GO) analysis based on $15 \%$ differences of methylation level between groups (significant according to Benjamin adjusted $p$ )

\begin{tabular}{|c|c|c|}
\hline Group/Term & N Genes* & $p$, Benjamini \\
\hline \multicolumn{3}{|l|}{ Cancer/Control } \\
\hline \multicolumn{3}{|l|}{$\underline{\text { Pathways }}$} \\
\hline hsa04360: Axon Guidance & 27 & $9.59 \mathrm{E}-06, .00261$ \\
\hline hsa05200: Pathways in Cancer & 53 & $3.21 \mathrm{E}-04, .0429$ \\
\hline hsa04015: Rap1 Signaling Pathway & 33 & $4.20 \mathrm{E}-04, .0375$ \\
\hline hsa04510: Focal Adhesion & 32 & $6.40 \mathrm{E}-04, .0428$ \\
\hline hsa04724: Glutamatergic Synapse & 21 & $8.63 \mathrm{E}-04, .046$ \\
\hline \multicolumn{3}{|l|}{ Biological Process } \\
\hline $\begin{array}{l}\text { GO:0007156 Homophilic Cell Adhesion via Plasma Membrane } \\
\text { Adhesion Molecules }\end{array}$ & 62 & $1.21 \mathrm{E}-27,4.99 \mathrm{E}-24$ \\
\hline GO:0007165 Signal Transduction & 138 & $3.71 \mathrm{E}-07,7.65 \mathrm{E}-04$ \\
\hline GO:0043547 Positive Regulation of GTPase Activity & 74 & $1.12 \mathrm{E}-05, .0153$ \\
\hline GO:0050885 Neuromuscular Process Controlling Balance & 14 & $3.22 \mathrm{E}-05, .0326$ \\
\hline GO:0007155 Cell Adhesion & 61 & $4.83 \mathrm{E}-05, .0391$ \\
\hline GO:0007399 Nervous System Development & 43 & $5.17 \mathrm{E}-05, .035$ \\
\hline GO:0016477 Cell Migration & 30 & $5.97 \mathrm{E}-05, .0346$ \\
\hline \multicolumn{3}{|l|}{$\underline{\text { Cellular Component }}$} \\
\hline GO:0005886 Plasma Membrane & 397 & $4.88 \mathrm{E}-08,3.30 \mathrm{E}-05$ \\
\hline \multicolumn{3}{|l|}{$\underline{\text { Molecular Function }}$} \\
\hline GO:0005509 Calcium Ion Binding & 119 & $1.45 \mathrm{E}-15,1.76 \mathrm{E}-12$ \\
\hline \multicolumn{3}{|l|}{$\underline{\text { Family/Control }}$} \\
\hline \multicolumn{3}{|l|}{$\underline{\text { Molecular Function }}$} \\
\hline GO:0005516 Calmodulin Binding & 28 & $3.88 \mathrm{E}-06, .00392$ \\
\hline \multicolumn{3}{|l|}{ Obesity/Control } \\
\hline \multicolumn{3}{|l|}{ Biological Process } \\
\hline $\begin{array}{l}\text { GO:0007156 Homophilic Cell Adhesion via Plasma Membrane } \\
\text { Adhesion Molecules }\end{array}$ & 32 & $1.04 \mathrm{E}-17,2.30 \mathrm{E}-04$ \\
\hline \multicolumn{3}{|l|}{$\underline{\text { Cellular Component }}$} \\
\hline GO:0005886 Plasma Membrane & 158 & $3.61 \mathrm{E}-06, .0014$ \\
\hline \multicolumn{3}{|l|}{ Molecular Function } \\
\hline GO:0005509 Calcium Ion Binding & 51 & $3.60 \mathrm{E}-09,2.29 \mathrm{E}-06$ \\
\hline
\end{tabular}

${ }^{*}$ Red fonts denote repeated components between the pairs of comparisons.

scanning the genome using $200 \mathrm{bp}$ tiling windows, when $10 \%$ of differential methylation level was used as criteria, 7327 DMRs were identified between CRC and control pair, 6072 between Family and control pair, and 2203 between obese and non-obese control pair. The decreased numbers of DMRs down the pairs of CRC, Family, obese groups paired with controls, depict the differences of association from CRC, to family members, and obese groups compared to the healthy non-obese group. The findings also suggested that adiposity may share similar disease development in biological process, cellular component, and molecular function, with CRC.

We identified 1778 known genes that were hyperor hypo-methylated in CRC group when compared to the 
control. Among the top 10 hyper- or hypo-methylated genes from $\mathrm{CRC} /$ control pair, most of DMRs have been reported as being differently expressed in or associated with CRC tumor tissue. PCNXL3 was reported to be one of the top 20 genes with the highest correlations with colon adenocarcinoma [42], MIR4285 and MIR3648 were shown to be differentially expressed in colon adenomas [43, 44], and MiR1247 as a potential tumor suppressive gene [45]. Bhatlekar et al showed that overexpression of HOXA4 and $H O X A 9$ contributes to self-renewal and overpopulation of stem cells in CRC [46]. HOXA4 has also been reported to be a potential tumor suppressive gene [47-49]. CLDN23 expression had been shown to be increased in CRC [50] and patients with down-regulation of CLDN23 was reported to have shorter overall survival [51]. GNAS mutations had been identified in several tumors of the endocrine system [52]. SLC2A1 (GLUT1) and SLC2A3 (GLUT3) genes were involved in glucose and insulin metabolism which played vital role in development of obesity, diabetes and CRC. MLH3 is a DNA MMR gene, which plays vital role in cancer development. FANCG is a DNA repair gene which is a candidate tumor suppressor gene. RPSA (also name as laminin receptor 1 ) transcript was shown to being higher in colon carcinoma tissue [53]. Therefore, those genes were involved in CRC and they may qualify to serve as candidate biomarkers for CRC diagnostic or may provide further understanding on CRC development.

Family members may share the genetic heritage and if lived in same household could share the habitat of similar dietary habits, lifestyles and the same environmental agents that could contribute to the same DNA methylation at some level. Therefore, we performed pair-wise comparisons of Cancer/control, Family/control, and obese/control with the methylation status among the four groups of Cancer, Family, obese, and control Five of six significant genes that played significant roles in cancer development or tumorigenesis, were shared by Cancer/control and Family/control pairs as presented in Figures 2 and 3. These genes included MSH2, SEPT9, GNAS, SLC2A1/GLUT1 and SLC2A3/GLUT [20-22], SLC2A1/GLUT1 and SLC2A3/ GLUT3. These genes were associated with poor prognosis for disease-free survival in rectal cancer [24-27], and aggressive CRC through a meta-analysis [28]. SEPT9 gene was reported as being a promising biomarker for early detection and screening of CRC [29, 30], which is also presented in our results using the blood samples. CAMK1, GLUT1/ SLC2A1 and GLUT3/SLC2A3 genes were involved in glucose and insulin metabolism that played vital role in development of obesity and diabetes [31].

We further performed $\mathrm{GO}$ analysis for both CRC and their family members in comparison to the non-obese healthy controls. However, only one molecular function showed significant difference between Family and control pair. Although Family/control pair shared some significant
DMRs with Cancer/control pair, no pathways and only one molecular function survived the FDR statistical tests. This may explain the differences on the methylation status associated with cancer development and cancer progression.

For obese and control paired comparison, we presented one significant biological process, one significant cellular component and one significant molecular function, named Homophilic Cell Adhesion via Plasma Membrane Adhesion Molecules (GO: 0007156), Plasma Membrane (GO: 0005886) and Calcium Ion Binding (GO: 0005509) respectively. And these results are repeated components with the Cancer/control paired tests. These shared components demonstrated the potential associations in the development of diseases for CRC and adiposity.

With the conceptualization of family-based study design, in this preliminary report, we have demonstrated the shared genetic and environmental influences, and epigenetics of methylation changes on DMRs and associated genes between CRC and their blood related family members in their genomes. We have also demonstrated the similar methylation changes for the obese subjects in relation to the CRC cases. In addition to many tumor/cancer related genes, we further demonstrated the importance of glucose transporter genes in the methylation pathways for the possible mechanisms of adiposity in promoting cancer progression. Additionally, we demonstrated that the methylation changes can be investigated using the blood samples for the whole human genome as our findings using the blood samples validated findings of tissuebased studies and extended findings from selected genes to the whole genome. Given that this is a first study for CRC cases involving their blood-related family members to examine shared genetic and environmental influences, and epigenetics within the family units, the findings from this demonstration/preliminary project with limited sample size needs to be further validated using larger samples. Our preliminary study provided evidences that these differentially methylated genes in the blood could potentially serve as candidate biomarkers for $\mathrm{CRC}$ diagnostic and may provide further understanding on CRC progression. Further studies are warranted to validate these methylation changes for diagnostic and prevention of CRC.

\section{MATERIALS AND METHODS}

\section{RRBS library preparation}

DNA was extracted from the whole blood of human subjects (CRC and their family members) using DNEasy blood and tissue kit (Qiagen, USA), following the manufacturer's protocol. Reduced representation bisulfite sequencing (RRBS) was performed on these DNA 
samples to identify genomic DNA methylation regions. On the RRBS process: restriction enzyme was used to digest $5 \mathrm{ng}$ genomic DNA in $200 \mu \mathrm{L}$ reaction buffer at $37^{\circ} \mathrm{C}$ overnight. The sticky ends produced by digestion were filled with CG nucleotides, and 3'A overhangs were added. Illumina sequencing adapters (Illumina, CA, USA) with 3'T overhangs, instead of standard adaptors contained in Illumina TruSeq library preparation kit, were ligated onto digested DNA following the manufacturer's protocols (Illumina TruSeq library preparation kit). Size selection was performed manually on a $3 \%$ nusieve agarose gel (Alphatech, New Zealand) to capture insert sizes of 150-250 bp based on previous studies [54]. Efficiency of adaptor ligation and size selection was determined by qualitative PCR. Bisulfite conversion of non-methylated cytosines was performed on $20 \mu \mathrm{L}$ size-selected fragments using an EZ-DNA bisulfite conversion kit (Zymo, CA, USA) following the manufacturer's instructions, except for a modification to bisulfite conversion conditions as recommended by Smith et al., 2009 [55]: $99^{\circ} \mathrm{C}$ for 5 minutes, $60^{\circ} \mathrm{C}$ for 25 minutes, $99^{\circ} \mathrm{C}$ for 5 minutes, $60^{\circ} \mathrm{C}$ for 85 minutes, $99^{\circ} \mathrm{C}$ for 5 minutes, $60^{\circ} \mathrm{C}$ for 175 minutes, $6 \times\left(95^{\circ} \mathrm{C}\right.$ for 5 minutes, $60^{\circ} \mathrm{C}$ for 90 minutes $)$. All PCR reactions for RRBS were purified using AMPure XP (Beckman Coulter, Brea, USA), analyzed on a bioanalyzer. The libraries were sequenced on two partial flow cells on an Illumina HiSeq 2000 sequencer and 50 bp paired-end reads.

RRBS data for 5 obese human subjects (GEO run number: SRR4048951, SRR4048952, SRR4048954, SRR4048955, and SRR4048957) and 5 non-obese healthy human subjects (GEO run number: SRR4048943, SRR4048945, SRR4048947, SRR4048948, and SRR4048949) were downloaded from GEO database (https:// www.ncbi.nlm.nih.gov/geo/query/acc.cgi?acc=GSE85928). Demographic characteristics of gender were matched between groups of obese/non-obese controls, and with the $\mathrm{CRC}$ and Family groups to the extent possible; and oldest age from the available controls on the GEO database were chosen, for pair-wise comparison with CRC cases and family members for further DMR analysis.

\section{Bioinformatics analysis}

The raw sequencing reads were cleaned using FASTQC software (Babraham Institute, Babraham, Cambridgeshire, United Kingdom) prior to alignment. Adapter and low-quality reads with a Phred score value of 20 or less were trimmed with Trim galore, a wrapper script using FASTQC and Cutadapt software. The FastQC analysis was then conducted to ensure that quality measures were met in the remaining reads after trimming. The remaining reads were aligned to the hg19 human reference genome by using Bismark with Bowtie 2 software (Babraham Institute, Babraham, Cambridgeshire, United Kingdom), and BAM file was produced. To increase the reliability of the alignments, the average alignment mapping quality (MAPQ) of the BAM file from Bismark was rechecked using SAMtools software [56]. All remaining samples had a MAPQ score greater than 38 , indicating the mismatching possibility being small, $p$ $<0.00016$. Samtools was used to get mpileup, and PERL scripts were used to determine $\mathrm{CpG}$ methylation and non$\mathrm{CpG}$ methylation to estimate the bisulfite conversion efficiency. All methylation information was extracted by Bowtie and transferred to a txt file that could be further analyzed and summarized by R program with Methylkit package [57].

\section{Detection of DMRs}

To determine differences in methylation between groups, the aligned extracted data from above were imported into the free open source R package. Percentage of methylation difference per base were calculated using methylKit [57] and DMCs were identified with a $>15 \%$ methylation difference and an adjusted $p$-value $<0.05$. eDMR (extended methylKit) were used to identified DMR with at least one DMC, at least three CpGs, a $>10 \%$ on mean methylation difference, and an adjusted $p$-value $<$ 0.05 . The $200 \mathrm{bp}$ non-overlapping windows was used to identify DMRs. The windows containing fewer than 5 CpGs were filtered out of the further analysis. The DMRs were annotated using the UCSC RefSeq tracks.

\section{Gene ontology and pathways analysis}

Annotated gene lists were submitted to the David functional annotation database. Significant gene ontology and biological pathways were selected based on Benjamin adjusted $p$ (Benjamin $p<0.05$ ). Student's $t$-test was used to examine whether methylation levels differed between one of the three groups and the healthy non-obese control group. To correct for multiple testing, the $p$ values were checked with FDR and adjusted $p$ values.

\section{Author contributions}

Conceived the concepts: S. Pamela K. Shiao; Wrote the first draft of the manuscript: Haiyan Xiao and S. Pamela K. Shiao; Data analysis: Haiyan Xiao, Lixin Dong, Pamela K. Shiao; Agreed with manuscript results and conclusions: all authors reviewed and approved of the final manuscript.

\section{ACKNOWLEDGMENTS}

The authors thank the facilitation of sequencing analysis at Baylor Scott \& White Research Institute Genomic Core Facility by Dr. Teodoro Bottiglieri, Center of Metabolomics, Institute of Metabolic Disease, Baylor Scott \& White Research Institute, Dallas, Texas. 


\section{CONFLICTS OF INTEREST}

The authors declare no conflict of interest.

\section{FUNDING}

Funding supports include the Doctoral Research Council Grants, Azusa Pacific University; Research Start-up fund from Augusta University awarded to the corresponding author.

\section{REFERENCES}

1. Siegel RL, Miller KD, Fedewa SA, Ahnen DJ, Meester RG, Barzi A, Jemal A. Colorectal cancer statistics, 2017. CA Cancer J Clin. 2017; 67:177-93. https://doi.org/10.3322/ caac. 21395

2. Siegel RL, Miller KD, Jemal A. Cancer statistics, 2018. CA Cancer J Clin. 2018; 68:7-30. https://doi.org/10.3322/ caac. 21442 .

3. You JS, Jones PA. Cancer genetics and epigenetics: two sides of the same coin? Cancer Cell. 2012; 22:9-20. https:// doi.org/10.1016/j.ccr.2012.06.008.

4. Costello JF, Plass C. Methylation matters. J Med Genet. 2001; 38:285-303. https://doi.org/10.1136/jmg.38.5.285.

5. Bird A. DNA methylation patterns and epigenetic memory. Genes Dev. 2002; 16:6-21. https://doi.org/10.1101/ gad.947102.

6. Jin $\mathrm{B}, \mathrm{Li} \mathrm{Y}$, Robertson KD. DNA methylation: superior or subordinate in the epigenetic hierarchy? Genes Cancer. 2011; 2:607-17. https://doi. org/10.1177/1947601910393957.

7. Oster B, Thorsen K, Lamy P, Wojdacz TK, Hansen LL, Birkenkamp-Demtröder K, Sørensen KD, Laurberg S, Orntoft TF, Andersen CL. Identification and validation of highly frequent $\mathrm{CpG}$ island hypermethylation in colorectal adenomas and carcinomas. Int J Cancer. 2011; 129:285566. https://doi.org/10.1002/ijc.25951.

8. Coppedè F, Migheli F, Lopomo A, Failli A, Legitimo A, Consolini R, Fontanini G, Sensi E, Servadio A, Seccia M, Zocco G, Chiarugi M, Spisni R, Migliore L. Gene promoter methylation in colorectal cancer and healthy adjacent mucosa specimens: correlation with physiological and pathological characteristics, and with biomarkers of onecarbon metabolism. Epigenetics. 2014; 9:621-33. https:// doi.org/10.4161/epi.27956.

9. Papadia C, Louwagie J, Del Rio P, Grooteclaes M, Coruzzi A, Montana C, Novelli M, Bordi C, de' Angelis GL, Bassett P, Bigley J, Warren B, Atkin W, Forbes A. FOXE1 and SYNE1 genes hypermethylation panel as promising biomarker in colitis-associated colorectal neoplasia. Inflamm Bowel Dis. 2014; 20:271-77. https:// doi.org/10.1097/01.MIB.0000435443.07237.ed.
10. Alegría-Torres JA, Baccarelli A, Bollati V. Epigenetics and lifestyle. Epigenomics. 2011; 3:267-77. https://doi. org/10.2217/epi.11.22.

11. Bartsch H, Nair J. Oxidative stress and lipid peroxidationderived DNA-lesions in inflammation driven carcinogenesis. Cancer Detect Prev. 2004; 28:385-91. https://doi.org/10.1016/j.cdp.2004.07.004.

12. Coppedè F. Epigenetic biomarkers of colorectal cancer: focus on DNA methylation. Cancer Lett. 2014; 342:238-47. https://doi.org/10.1016/j.canlet.2011.12.030.

13. Fardet A, Druesne-Pecollo N, Touvier M, Latino-Martel P. Do alcoholic beverages, obesity and other nutritional factors modify the risk of familial colorectal cancer? A systematic review. Crit Rev Oncol Hematol. 2017; 119:94-112. https:// doi.org/10.1016/j.critrevonc.2017.09.001.

14. Holmes MV, Pulit SL, Lindgren CM. Genetic and epigenetic studies of adiposity and cardiometabolic disease. Genome Med. 2017; 9:82. https://doi.org/10.1186/ s13073-017-0474-5.

15. Almén MS, Nilsson EK, Jacobsson JA, Kalnina I, Klovins J, Fredriksson R, Schiöth HB. Genome-wide analysis reveals DNA methylation markers that vary with both age and obesity. Gene. 2014; 548:61-67. https://doi.org/10.1016/j. gene.2014.07.009.

16. Alfadda AA, Sallam RM, Gul R, Hwang I, Ka S. Endophilin A2: a potential link to adiposity and Beyond. Mol Cells. 2017; 40:855-63. https://doi.org/10.14348/ molcells.2017.0137.

17. Muppala S, Konduru SK, Merchant N, Ramsoondar J, Rampersad CK, Rajitha B, Mukund V, Kancherla J, Hammond A, Barik TK, Mannarapu M, Alam A, Basha R, et al. Adiponectin: its role in obesity-associated colon and prostate cancers. Crit Rev Oncol Hematol. 2017; 116:12533. https://doi.org/10.1016/j.critrevonc.2017.06.003.

18. Babenko VN, Chadaeva IV, Orlov YL. Genomic landscape of $\mathrm{CpG}$ rich elements in human. BMC Evol Biol. 2017; 17:19. https://doi.org/10.1186/s12862-016-0864-0.

19. Lövkvist C, Dodd IB, Sneppen K, Haerter JO. DNA methylation in human epigenomes depends on local topology of CpG sites. Nucleic Acids Res. 2016; 44:512332. https://doi.org/10.1093/nar/gkw124.

20. Lynch HT, Snyder CL, Shaw TG, Heinen CD, Hitchins MP. Milestones of Lynch syndrome: 1895-2015. Nat Rev Cancer. 2015; 15:181-94. https://doi.org/10.1038/nrc3878.

21. Ramsoekh D, Wagner A, van Leerdam ME, Dooijes D, Tops CM, Steyerberg EW, Kuipers EJ. Cancer risk in MLH1, MSH2 and MSH6 mutation carriers; different risk profiles may influence clinical management. Hered Cancer Clin Pract. 2009; 7:17. https://doi.org/10.1186/1897-4287-7-17.

22. Zauber P, Marotta SP, Sabbath-Solitare M. GNAS gene mutation may be present only transiently during colorectal tumorigenesis. Int J Mol Epidemiol Genet. $2016 ; 7: 24-31$. 
23. Wu Y, Berends MJ, Sijmons RH, Mensink RG, Verlind E, Kooi KA, van der Sluis T, Kempinga C, van dDer Zee AG, Hollema H, Buys CH, Kleibeuker JH, Hofstra RM. A role for MLH3 in hereditary nonpolyposis colorectal cancer. Nat Genet. 2001; 29:137-38. https://doi.org/10.1038/ ng1001-137.

24. Macheda ML, Rogers S, Best JD. Molecular and cellular regulation of glucose transporter (GLUT) proteins in cancer. J Cell Physiol. 2005; 202:654-62. https://doi.org/10.1002/ jcp.20166.

25. Chung FY, Huang MY, Yeh CS, Chang HJ, Cheng TL, Yen LC, Wang JY, Lin SR. GLUT1 gene is a potential hypoxic marker in colorectal cancer patients. BMC Cancer. 2009; 9:241. https://doi.org/Artn24110.1186/1471-2407-9-241.

26. Krzeslak A, Wojcik-Krowiranda K, Forma E, Jozwiak P, Romanowicz H, Bienkiewicz A, Brys M. Expression of GLUT1 and GLUT3 glucose transporters in endometrial and breast cancers. Pathol Oncol Res. 2012; 18:721-28. https://doi.org/10.1007/s12253-012-9500-5.

27. Carvalho KC, Cunha IW, Rocha RM, Ayala FR, Cajaíba MM, Begnami MD, Vilela RS, Paiva GR, Andrade RG, Soares FA. GLUT1 expression in malignant tumors and its use as an immunodiagnostic marker. Clinics (São Paulo). 2011; 66:965-72. https://doi.org/10.1590/ S1807-59322011000600008.

28. Yang J, Wen J, Tian T, Lu Z, Wang Y, Wang Z, Wang $X$, Yang Y. GLUT-1 overexpression as an unfavorable prognostic biomarker in patients with colorectal cancer. Oncotarget. 2017; 8:11788-96. https://doi.org/10.18632/ oncotarget.14352.

29. Church TR, Wandell M, Lofton-Day C, Mongin SJ, Burger M, Payne SR, Castaños-Vélez E, Blumenstein BA, Rösch T, Osborn N, Snover D, Day RW, Ransohoff DF, and PRESEPT Clinical Study Steering Committee, Investigators and Study Team. Prospective evaluation of methylated SEPT9 in plasma for detection of asymptomatic colorectal cancer. Gut. 2014; 63:317-25. https://doi.org/10.1136/ gutjnl-2012-304149.

30. Li Y, Song L, Gong Y, He B. Detection of colorectal cancer by DNA methylation biomarker SEPT9: past, present and future. Biomarkers Med. 2014; 8:755-69. https://doi. org/10.2217/bmm.14.8.

31. Anjosa ZP, Santos MM, Rodrigues NJ, Lacerda GA, Araujo J, Silva JA, Tavares NA, Guimarães RL, Crovella $\mathrm{S}$, Brandão LA. Polymorphism in ficolin-1 (FCN1) gene is associated with an earlier onset of type 1 diabetes mellitus in children and adolescents from northeast Brazil. J Genet. 2016; 95:1031-34. https://doi.org/10.1007/ s12041-016-0719-x.

32. Yang L, Rau R, Goodell MA. DNMT3A in haematological malignancies. Nat Rev Cancer. 2015; 15:152-65. https:// doi.org/10.1038/nrc3895.

33. Huang W, Sherman BT, Lempicki RA. Systematic and integrative analysis of large gene lists using DAVID bioinformatics resources. Nat Protoc. 2009; 4:44-57. https://doi.org/10.1038/nprot.2008.211.

34. Huang W, Sherman BT, Lempicki RA. Bioinformatics enrichment tools: paths toward the comprehensive functional analysis of large gene lists. Nucleic Acids Res. 2009; 37:1-13. https://doi.org/10.1093/nar/gkn923.

35. Li H, Liu JW, Liu S, Yuan Y, Sun LP. Bioinformatics-based identification of methylated-differentially expressed genes and related pathways in gastric cancer. Dig Dis Sci. 2017; 62:3029-39. https://doi.org/10.1007/s10620-017-4740-6.

36. Duman-Scheel M. Deleted in Colorectal Cancer (DCC) pathfinding: axon guidance gene finally turned tumor suppressor. Curr Drug Targets. 2012; 13:1445-53. https:// doi.org/10.2174/138945012803530215.

37. Neapolitan R, Horvath CM, Jiang X. Pan-cancer analysis of TCGA data reveals notable signaling pathways. BMC Cancer. 2015; 15:516. https://doi.org/10.1186/ s12885-015-1484-6.

38. Ishida D, Kometani K, Yang H, Kakugawa K, Masuda K, Iwai K, Suzuki M, Itohara S, Nakahata T, Hiai H, Kawamoto H, Hattori M, Minato N. Myeloproliferative stem cell disorders by deregulated Rap1 activation in SPA1-deficient mice. Cancer Cell. 2003; 4:55-65. https://doi. org/10.1016/S1535-6108(03)00163-6.

39. Eke I, Cordes N. Focal adhesion signaling and therapy resistance in cancer. Semin Cancer Biol. 2015; 31:65-75. https://doi.org/10.1016/j.semcancer.2014.07.009.

40. Zhang YL, Wang RC, Cheng K, Ring BZ, Su L. Roles of Rap1 signaling in tumor cell migration and invasion. Cancer Biol Med. 2017; 14:90-99. https://doi.org/10.20892/j. issn.2095-3941.2016.0086.

41. Prickett TD, Samuels Y. Molecular pathways: dysregulated glutamatergic signaling pathways in cancer. Clin Cancer Res. 2012; 18:4240-46. https://doi.org/10.1158/1078-0432. CCR-11-1217.

42. Kim P, Cheng F, Zhao J, Zhao Z. ccmGDB: a database for cancer cell metabolism genes. Nucleic Acids Res. 2016; 44:D959-68. https://doi.org/10.1093/nar/gkv1128.

43. Zhang Y, Li M, Ding Y, Fan Z, Zhang J, Zhang H, Jiang B, Zhu Y. Serum MicroRNA profile in patients with colon adenomas or cancer. BMC Med Genomics. 2017; 10:23. https://doi.org/10.1186/s12920-017-0260-7.

44. Mullany LE, Herrick JS, Wolff RK, Stevens JR, Slattery ML. Association of cigarette smoking and microRNA expression in rectal cancer: insight into tumor phenotype. Cancer Epidemiol. 2016; 45:98-107. https://doi. org/10.1016/j.canep.2016.10.011.

45. Liang JJ, DeJulius KL, Jarrar A, Ting A, Church J, Kalady MF. Potential tumor suppressor miR-1247 is downregulated in $\mathrm{CpG}$ island methylator phenotype colon cancers. J Am Coll Surgeons. 2012; 215:S11. https://doi. org/10.1016/j.jamcollsurg.2012.06.053.

46. Bhatlekar S, Viswanathan V, Fields JZ, Boman BM. Overexpression of HOXA4 and HOXA9 genes promotes 
self-renewal and contributes to colon cancer stem cell overpopulation. J Cell Physiol. 2018; 233:727-35. https:// doi.org/10.1002/jcp.25981.

47. Morgan R, Simpson G, Gray S, Gillett C, Tabi Z, Spicer J, Harrington KJ, Pandha HS. HOX transcription factors are potential targets and markers in malignant mesothelioma. BMC Cancer. 2016; 16:85. https://doi.org/10.1186/ s12885-016-2106-7.

48. Klausen C, Leung PC, Auersperg N. Cell motility and spreading are suppressed by HOXA4 in ovarian cancer cells: possible involvement of beta1 integrin. Mol Cancer Res. 2009; 7:1425-37. https://doi.org/10.1158/1541-7786. MCR-08-0466.

49. Ota T, Klausen C, Clara Salamanca M, Woo HL, Leung PC, Auersperg N. Expression and function of HOXA genes in normal and neoplastic ovarian epithelial cells. Differentiation; research in biological diversity. 2009; 77:162-71. https://doi.org/10.1016/j.diff.2008.09.018.

50. Maryan N, Statkiewicz M, Mikula M, Goryca K, Paziewska A, Strzałkowska A, Dabrowska M, Bujko M, Ostrowski J. Regulation of the expression of claudin 23 by the enhancer of zeste 2 polycomb group protein in colorectal cancer. Mol Med Rep. 2015; 12:728-36. https://doi.org/10.3892/ mmr.2015.3378.

51. Pitule P, Vycital O, Bruha J, Novak P, Hosek P, Treska V, Hlavata I, Soucek P, Kralickova M, Liska V. Differential expression and prognostic role of selected genes in colorectal cancer patients. Anticancer Res. 2013; 33:4855-65.
52. Weinstein LS, Yu S, Warner DR, Liu J. Endocrine manifestations of stimulatory $G$ protein alpha-subunit mutations and the role of genomic imprinting. Endocr Rev. 2001; 22:675-705. https://doi.org/10.1210/edrv.22.5.0439.

53. Lu CL, Xu J, Yao HJ, Luo KL, Li JM, Wu T, Wu GZ. Inhibition of human $67-\mathrm{kDa}$ laminin receptor sensitizes multidrug resistance colon cancer cell line SW480 for apoptosis induction. Tumour Biol. 2016; 37:1319-25. https://doi.org/10.1007/s13277-015-3873-5.

54. Doherty R, Couldrey C. Exploring genome wide bisulfite sequencing for DNA methylation analysis in livestock: a technical assessment. Front Genet. 2014; 5:126. https://doi. org/10.3389/fgene.2014.00126.

55. Smith ZD, Gu H, Bock C, Gnirke A, Meissner A. Highthroughput bisulfite sequencing in mammalian genomes. Methods. 2009; 48:226-32. https://doi.org/10.1016/j. ymeth.2009.05.003.

56. Li H, Handsaker B, Wysoker A, Fennell T, Ruan J, Homer N, Marth G, Abecasis G, Durbin R, and 1000 Genome Project Data Processing Subgroup. The Sequence Alignment/Map format and SAMtools. Bioinformatics. 2009; 25:2078-79. https://doi.org/10.1093/bioinformatics/ btp352.

57. Akalin A, Kormaksson M, Li S, Garrett-Bakelman FE, Figueroa ME, Melnick A, Mason CE. methylKit: a comprehensive $\mathrm{R}$ package for the analysis of genome-wide DNA methylation profiles. Genome Biol. 2012; 13:R87. https://doi.org/10.1186/gb-2012-13-10-r87. 